\title{
THE PROVIDENCE OF GOD IN THE ACTS OF THE APOSTLES
}

\author{
Jonathan Huggins \\ Systematic Theology and Ecclesiology \\ Stellenbosch University
}

\begin{abstract}
In order to better understand the context of the book of Acts I will look at how the people of his day understood divine providence. Was the author (presumably Luke) presenting an original theological concept? Or was he modifying, or making use of, notions of divine providence already available to his audience? Was there enough overlap between Jewish and Greco-Roman understandings of this idea for Luke to make a commonly understood appeal? Luke, as historian and theologian, clearly appeals to divine providence in his portrayal of how the early church was formed, spread and organized. To begin to answer these kinds of questions, I will begin by looking at the Jewish background and then examine the Greco-Roman background. This will enable us to make better sense of the form of Luke's presentation of the early church, as well as to understand a prevailing theology of the Holy Spirit present in the early church.
\end{abstract}

Key Words: Acts; Providence; Luke; Holy Spirit; Church

\section{Introduction}

The idea of 'providence' can mean 'foresight or making provision beforehand'. ${ }^{1}$ With reference to God, we are speaking of his universal governance of all things, from the creation of the world to its daily maintenance. In theology, providence has been defined as "the sovereign, divine superintendence of all things, guiding them toward their divinely predetermined end in a way that is consistent with their created nature, all to the glory and praise of God." " But the idea of providence itself was not only a Christian notion. Rather, it was a rather popular subject in both the Jewish and Greco-Roman world of the $1^{\text {st }}$ century. A uniquely Christian understanding of God's providence underlies Luke's presentation and description of the early church in the book of Acts. In this article I wish to suggest that Acts presents the providential work of the triune God in at least four areas: in establishing the new community, empowering their ministry, directing their mission, and informing their preaching. For the common people among both Jews and Gentiles, this understanding of divine providence was well accepted.

In order to better understand the context of Luke's readers I will look at how the people of his day understood divine providence. Was Luke presenting an original theological concept? Or was he modifying, or making use of, notions of divine providence already available to his audience? Was there enough overlap between Jewish and Greco-Roman understandings of this idea for Luke to make a commonly understood appeal? To begin to

\footnotetext{
$1 \quad$ Walter A Elwell, "Providence of God”, Evangelical Dictionary of Biblical Theology, ed. Walter A Elwell. Grand Rapids: Baker Books, 1996:650.

2 Ibid:650.
} 
answer these kinds of questions, I will begin by looking at the Jewish context and then we will exam the Greco-Roman context.

\section{Jewish Background}

From their own intertestamental literature the Jews speak of God as being in total control. The Wisdom of Solomon says, "But it is your providence, O Father, that steers its course ... it is your will that works of your wisdom should not be without effect; therefore people trust their lives even to the smallest piece of wood, and passing through the billows on a raft they come safely to land" (14:3-5). In this sense they understood that their lives were in God's hands and that His will was both good and certain. And again they say, "But as His will in Heaven may be, so shall He do" (1 Maccabees 3:60). And these thoughts are consistent with all the Old Testament's teaching on God's sovereign and universal rule. ${ }^{3}$ The subject of fate, or providence, was also discussed among the Pharisees, Sadducees, and the Essenes. Josephus writes concerning them:

Now for the Pharisees, they say that some actions, but not all, are the work of fate, and some of them are in our own power, and that they are liable to fate, but are not caused by fate. But the sect of the Essenes affirm[s] that fate governs all things, and that nothing befalls men but what is according to its determination. And for the Sadducees, they take away fate, and say there is no such thing, and that the events of human affairs are not at its disposal; but they suppose that all our actions are in our power, so that we are ourselves the causes of what is good, and receive what is evil from our own folly. ${ }^{4}$

Being that the Pharisees had greater popular appeal, combined with the fact that the teaching of Scripture is held sacred, the typical Jewish person would certainly hold a strong view of Yahweh's universal rule and control. Just the same, God was no distant disinterested deity. He was close and cared about His people. They speak of God's faithfulness, His mercy and steadfast love. God is portrayed as a Father who punishes and rewards His people according to their rebellion or obedience. Perhaps the delay in the fulfillment of God's promises caused the Sadducees to reject the idea of providential control in all things. It is difficult to say because God is portrayed as sovereign in the Torah, which was the only scripture they accepted.

The Pharisees and the Essenes saw themselves as living near to or in the midst of prophetic fulfillment. Therefore, their idea of providence was very strong. ${ }^{5}$ The Essenes believed, "For beyond You there is no perfect path and without Your will, nothing comes to be. You have taught all knowledge and all that exists is so by Your will" (Rule of the Community 11:17-20). ${ }^{6}$ This belief persists into the New Testament period. Outside the New Testament the Christian understanding of God's providence can be seen in the

See I Chron. 29:11-12; Psalm 24:1;115:3;135:6

4 Josephus, Antiquities of the Jews, 8.5.9, (translation William Whiston). Lynn, Massachusetts: Hendrickson Publishers, 1904. See also Josephus Wars of the Jews2.8.14 "The Pharisees are those who are esteemed most skillful in the exact explication of their laws ... they ascribe all to fate (or providence) and to God, and yet allow, that to act what is right, or the contrary, is principally in the power of men, although fate does cooperate in every action. But the Sadducees ... take away fate entirely, and suppose that God is not concerned in our doing or not doing what is evil; and they say that to act what is good, or what is evil, is at men's own choice, and that the one or the other belongs so to everyone, that they may act as they please."

5 For Jewish understanding of the nature of God, see Julius Scott, Jewish Backgrounds of the New Testament. Grand Rapids: Baker Books, 1995:266-269.

6 For more on religious ideas in Judaism, see Readings from the First Century World, edited by Walter Elwell and Robert W Yarbrough. Grand Rapids: Baker Books, 1998:97-121. 
writings of the early Christians. The apostles may have exhorted the people, "Accept as blessings the casualties that befall you, assured that nothing happens without God" (The Didache 2:10).

\section{Greco-Roman Background}

Greek thought on this doctrine is typified in the debates between the Stoic and Epicurean philosophers. The Stoics more faithfully represent the 'classical' understanding of divine providence. This classical understanding may be seen in Cleanthes' poem 'Hymn to Zeus' $\left(3^{\text {rd }}\right.$ Century BC):

The beginning of the world was from thee: and with law thou rulest over all things ... the whole order of the heavens obeyeth thy word: as it moveth around the earth ... nor is anything done upon earth apart from thee: nor in the firmament, nor in the seas: save that which the wicked do by their own folly.

Perhaps too, the Stoics are influenced by Plato's philosophy. Plato believed in a form of soft causality, defining God as the creator of intelligence and the animating principle at work in the world. Plato writes, "God, if he be good, is not the author of all things, as many assert, but he is the cause of a few things only, and not of most things that occur to men. For few are the goods of human life, and many are the evils, and the good is to be attributed to God alone; of the evils the causes are to be sought elsewhere, and not in him" (Republic, bk. 2, 1:643.). ${ }^{8}$

Cicero accepted the Stoic belief in the providence of God, but he softened their hard determinism. Cicero writes, "The world and all its parts were set in order at the beginning and have been governed for all time by divine providence" (De Natura Deorum, bk. 2, 167). ${ }^{9}$ However, in saying this, Cicero also denies that God has any foreknowledge of future events (See De Divinationei). Cicero's De Fato is a significant work because here we see his 'soft determinism.' He writes:

For it does not follow that if differences in men's propensities are due to natural and antecedent causes, therefore our wills and desires are also due to natural and antecedent causes, for if that were the case, we should have no freedom of the will at all. ${ }^{10}$

Seneca's work is also important concerning this doctrine. He believed in a benevolent and rational determinism where God favours the good. He would even argue that disasters come for good purpose. He writes:

To be always happy and to pass through life without vexation of mind is to be ignorant of the other side of human life. You are a great man, but how am I to know it, if fortune does not give you an opportunity of showing your virtue? You went into the Olympian games, but no one besides yourself: you have the crown, but not the victory...Misfortune is virtue's opportunity... God has considered us worthy on whom to try how much human nature can endure...Is it not better for them to endure continual misfortune, summoning virtue to their aid, than to be ruined by an unceasing and immoderate prosperity? ${ }^{11}$

7 Helenistic Commentary to the New Testament, eds. M Eugene Boring, Klaus Berger, and Carsten Cople. Nashville: Abingdon Press, 1995:326.

8 For a thorough discussion of Plato's understanding of providence, see Benjamin Farley, The Providence of God; The Greek and Roman Philosophical Heritage. Grand Rapids: Baker Books, 1988:54-57.

9 Quoted in Farley page 68

10 From De Fato, by Cicero, quoted in Farley

11 Seneca, De Providentia, 4. Trans. William Bell Langsdorf. New York: G.P. Putnam's Sons, 1900. 
To summarize Seneca's philosophy on providence, he writes:

I suffer no constraint, I endure nothing against my will, nor am I a slave to God, but I am in harmony with him; and so much the more because I know that all things move on forever according to a certain and fixed law. The fates guide us and the first hour of our birth determines how much time is allotted to each one of us. One cause depends upon another and a long chain of events influences public and private affairs. Therefore everything must be bravely endured, because all things do not, as we think, merely happen, but come according to a fixed law. It was determined long ago at what you should rejoice, and at what you should weep... For this we are destined... What is the part of a good man? To submit himself to destiny... The creator and ruler of all has indeed written the decrees of fates, but he also follows them. ${ }^{12}$

The Epicurean philosophers depart from the classically held ideas. For them there is not even an immanent principle of reason (Logos) within the universe. Their emphasis is upon life here and now. They believe this is the only life we will have and that there are no supernatural beings to fear or obey. Therefore, humans should seek only to find the pleasure of physical and mental repose. These Epicureans were of course not too impressed with Paul's message emphasizing an incarnate God and a resurrected life. ${ }^{13}$

The fundamental difference between Greek philosophy and Jewish understanding of providence is the character, or nature, or the divine. Elwell points out that the Greeks emphasize the "impersonal, the rational, nature of the divine imminent principle that could be approached by human minds." 14 The Jews, however, understand God as a personal being who draws his people to faith and trust in his steadfast love and purpose. Elwell also comments that Jesus made a profound contribution to this understanding. God is the Heavenly Father who continuously cares for his helpless creation. He calls us to trust and believe him and not necessarily understand all that he does. ${ }^{15}$

And so we see that 'providence' was not only a popular subject of the day, it was also a much-debated issue between different schools of philosophy. Just the same, we may be sure that both Jews and Greeks largely held to an idea of a sovereign and providential God, or gods.

\section{Providence in Acts: Scholarly Analysis}

Luke's portrayal of God in Acts illustrates this providential power. Those who receive the gospel and read Luke's work are to understand that what is happening is not the work of mere men. The message communicates generally well given the historical context.

Many scholars have noted Luke's use of the word dei ('it is necessary'). For instance, Alan Thompson writes. "one of the ways the book of Acts evidences a theological understanding of history in which God is in control and fulfilling his covenant promises is in the prominence of terms that indicate divine sovereignty. The most prominent term in Acts that draws attention to 'divine necessity' is dei, 'it is necessary". ${ }^{16}$ Earl Richard speaks of $d e i$ in terms of Divine purpose. God accomplishes His purpose through

\footnotetext{
Seneca, 5 .

SR Obitts, “Epicureanism”, Evangelical Dictionary of Theology. Grand Rapids: Baker Books, 1984:358.

Elwell, "Providence of God", EDBT, page 651.

Ibid.

16 Alan J Thompson, The Acts of the Risen Lord Jesus: Luke's Account of God's Unfolding Plan. Downers Grove: IVP, 2011:30.
} 
supernatural intervention or through the Old Testament and its interpretation. ${ }^{17}$ HJ Cadbury comments, "One feature of Luke's work that might be conscious intention, quite as well as traditional motif or subconscious conviction, is the evidence of divine guidance and control that pervades it."18 Many other scholars have seen Luke's emphasis on Divine Providence. Erich Fascher's essay sets Luke's idea of providence firmly in line with the Old Testament and with Paul. However, Sigfried Schulz's opinion is that Luke-Acts reflects a Hellenized understanding. Fasher's argument is that a personal deity is in view here, not the impersonal powers of 'fate'. But Schulz argues that Luke's narrative reflects a dependence on God's inaccessible power and plan. This power cannot be thwarted nor resisted. God's providence replaces the importance of Scripture, thus reflecting a Hellenistic understanding of fate, though now ascribed to the Father of Jesus Christ. ${ }^{19}$ Cosgrove disagrees with both men saying that they overly restrict Luke and take away any originality in his usage and understanding of terms. They have defined dei and Luke in too narrow of terms. While holding that "there is a firm confidence expressed that history remains entirely in God's hands," ${ }^{20}$ Cosgrove writes that "the Lukan dei, even where it has the divine will in view, should not be regarded as a terminus technicus for the divine necessity." ${ }^{21}$ He points out that the word is used in different ways throughout Luke-Acts. He defines three shades of meaning to dei. First, it is used to point back to God's ancient plan. The 'proof from prophecy' method is used here. This 'grounds the kerygmatic history in divine sanction. ${ }^{22}$ The phrase is also used as a summons to obedience. This focuses on the human side of the mission. Jesus and Paul are both presented as taking the divine summons and executing, even protecting, God's purpose. The third usage is found in the way in which God intervenes to ensure His purpose prevails. This occurs in the jailbreaks or coercions to obedience as in the case of Zechariah. Cosgrove's desire is to show that Luke is not preoccupied with God's determinism power (which he calls 'fatalism'). He certainly holds that Luke is demonstrating that God is in control. God can do whatever He wants and is never bound. His purposes and plans will come to pass even if He has to intervene to make them happen. But the universe is not so fixed that God need not help out His people. ${ }^{23}$

Cosgrove makes a valid point in his article. Luke does use the term dei in a few different ways, and they are not always dependent on God's providential plan. However, even if God does intervene and summons people to obey Him, there still remains the possibility that God has ordered those things to be as well. It seems that there was purpose even in Zechariah's muteness. And supernatural displays to speak to or rescue his people are not contrary to universal control. Such things do not hurt the glory of God, but rather result in His praise. The overriding theme in Luke's use of dei remains focused on the fact that what is happening in Acts is not of human design or strength. God is behind everything, even where human agents are involved. This will be demonstrated in the next part of the essay.

17 Earl Richard, "Luke-Acts; The Divine Purpose", in New Perspectives from the Society of Biblical Literature Seminar, ed. Charles H Talbert. New York: Crossroad, 1984:192-194.

18 See HJ Cadbury, The Making of Luke-Acts. New York: Macmillan, 1927:303-305. Quoted by Charles H Cosgrove, "The Divine Dei in Luke-Acts", Novum Testamentum XXVI, 2 (1984).

19 Both Fascher and Schulz are referenced in Cosgrove's article. For more on their views, see Sigfried Schulz, "Gottes Vorsehung bei Lukas," ZNW 54, 1963:104-116; and Erich Fascher, "Theologische Beobachtungen zu dei".

20 Cosgrove, 186-187.

$21 \quad$ Ibid: 173.

22 Ibid: 189.

23 See Cosgrove's full article to understand his position better. 
If we take Luke to be more than an historian, and as in fact also a Christian theologian, then we must take his theology seriously. How does he portray God, Jesus and the Holy Spirit? Mark Alan Powell points out that much of what Luke thinks about God is implied through the narrative. But one of the overriding features is that God controls history. "For Luke, God is the lord of history. God determines what will happen, as well as when, where, and how it will happen. God is in charge." 24 Powell also deals with Luke's use of dei, which illustrates his profound sense of divine purpose. He points also to Robert O'Toole's The Unity of Luke's Theology. O'Toole looks at the emphasis upon the foreknowledge, will, plan, and purpose of God in Luke-Acts. Powell writes:

God fulfills and brings to pass events predicted in the scriptures (Luke 1:20;4:21;21:24; Acts 1:16;3:18;13:27;14:26). God determines the timetables and geographical boundaries of history (Acts 17:26) as well as the fate of individuals including Jesus (Luke 22:22; Acts 2:23;10:42;17:31). Times and seasons are set by God, as are the purposes for individual lives (Acts13:47). God appoints the temporal (Acts 22:10) and the eternal (Acts 13:48) destiny of people. ${ }^{25}$

Powell's summary of Luke's theology is that it is 'theocentric', 'christocentric', and 'pneumocentric' in that the triune God is a unified and sovereign body directing, establishing and empowering the people of God and the plan of God. ${ }^{26}$

Jacob Jervell agrees with Powell's assessment. He writes, "the church does not lead and guide itself; God does through the Spirit, voices, visions, etc." ${ }^{27}$ Jervell thinks that Luke's understanding of God as controlling history is the anchor, or foundation of Acts. It is impossible for men to resist God's will, "at least in the long run.",28

The important work by John Squires also largely confirms what I am suggesting about the use of divine providence in Acts. He writes:

It is the theme of providence which, as we have seen, draws all of these interests and aims together. Providence was a central theme in Hellenistic historiography, a theme which was also central to the Hebrew scriptures, albeit in different terminology. Providence was a central aspect of philosophical discussion and theory, and it had an apologetic function in the less technical writings of Hellenism. Providence in the histories had a religious application; it emphasized certain rituals at the expense of others. All of these elements are found in Luke-Acts in association with the theme of 'the plan of God', which provides us with a key to unlock some of the complexities of LukeActs. $^{29}$

Derek Morphew agrees by stating, "Luke was clearly aware of the role beliefs in providence had in Greek historiography." 30 His work also includes a helpful chart of passages taken from both Luke's Gospel and Acts wherein the "relentless and determined will of God" are demonstrated by the wording of the text. ${ }^{31}$

\footnotetext{
Mark Alan Powell, What are They Saying About Acts? New York: Paulist Press, 1991:39.

Ibid:39, referencing O'Toole's work.

Ibid: 57.

Jacob Jervell, The Theology of the Acts of the Apostles. Cambridge: University Press, 1996:51.

Ibid:129. This qualification doesn't take away from God's ultimate control. But it also maintains some human "freedom".

John T Squires, The Plan of God in Luke-Acts. Cambridge University Press, 2004:192.

Derek Morphew, The Mission of the Kingdom. Cape Town: Vinyard International Publishing, 2011:48.

Ibid:45-47 for chart.
} 
This scholarly consensus gives me confidence to argue for the display and use of divine providence in Acts in particular ways. To that discussion I now move.

\section{How Divine Providence is Portrayed in Acts}

Some scholars may have a difficult time with Luke's strong emphasis on Divine providence at work in every fibre of the early Christian's lives. Luke clearly emphasizes it. However, Luke does not take away entirely the notions of human responsibility. In fact, he maintains those as well (e.g. Ananias and Sapphira, Acts 5:1-11). Luke is not writing a systematic theology. It may, however, be viewed as a theological history in many respects. And within this framework we see both Divine Sovereignty and human responsibility. But they are not equal opposites. For they are neither equal in power, nor are they always in disharmony with each other. And Luke's emphasis is clearly upon the providential power of God at work despite human resistance and fallibility. God is accomplishing all His good purpose and plans. And Luke shows us God doing this in establishing the new community, empowering their ministry, directing the mission, and informing all their preaching. We will now turn to examine Luke's portrayal of this truth.

One of the first places that we see divine providence at work is in the establishment of the church in the choosing of Matthias to replace Judas Iscariot (Acts 1:24-26). Peter speaks as though the Psalm passages demand that such a decision be made. The believers pray and set forth two men who meet the given qualifications. They cast the lots and the Lord's hand (Prov 16:33) leads to Matthias, thus bringing the number of apostles back to twelve.

The Holy Spirit reportedly 'comes' on the day of Pentecost, which many consider the birthday of the church. This event gave the disciples power to do what they could not do on their own beforehand. They find themselves possessing a new kind of power. This power is demonstrated in that some 3000 Jews are converted that day, believing what Peter preached (2.41). Luke's comment on the event is revealing, "the Lord added to their number day by day those who were being saved (2.47)." ${ }^{\prime 32}$ The same belief in divine providence is seen in the conversion of Saul of Tarsus to the new faith in Christ, $(9.15 ; 22.10,14-21 ; 26.14-18)$. God appears to establish the Jewish and Gentile believers in their faith through conversions by the Spirit and by Spirit-empowered leadership. Philip is sent to bring the gospel to an Ethiopian eunuch (8.26-39). And the great Apostle Peter is sent to a home full of Gentiles under the direction of the Holy Spirit (10.19-20). Here the Holy Spirit gives birth to a company of Gentile Christians (10.44-48)! And soon afterwards, God would give the Gentile believers good leadership through Paul and Barnabas (11.22-26). Peter comments on Gentile salvation as an established issue at the council in Jerusalem. He tells them that God made the choice to give the Gentiles the Spirit just as they themselves had received it (15.7-11). And the narrative goes on to speak of how the Lord chose overseers in the churches to help them remain strong and faithful (20.28). All of this goes to show that Luke understands that God is giving birth to this community as a part of His good will and plan. The people alone are not making these things happen.

Luke also shows the providence of God at work in directing the mission of the church. Right from the beginning Jesus tells his followers that they will be His witnesses in Jerusalem, Judea, Samaria, to the ends of the earth (1.8). And the narrative follows this very

32 See also $6.7 ; 9.31 ; 11.21 ; 13.48 ; 14.27 ; 16.14 ; 19.20 ; 21.19$ for more on God's providence in bringing salvation to establish His church. 
course of witnessing action. In those early days the Spirit directed them to proclaim in specific places whether that was the temple $(5.19-20)$, to certain persons $(8.26,39 ; 10.19$ $20)$ or in a certain region (16.6-10). Peter is himself very clear when defending his speaking and eating with Gentiles, that "the Spirit told me to go with them, making no distinction" (11.12). And when the Lord was ready to send out Barnabas and Paul on the mission field, it was the Holy Spirit who spoke to them through prophetic utterance, "Set apart for me Barnabas and Saul for the work to which I have called them" (13.2). And in their mission the Lord directs them as well. The Spirit (also called the 'Spirit of Jesus') does not permit them to go some places while directing them elsewhere through the means of visions or prophecies (16.6-10). Sometimes the Lord would speak to Paul in the night to tell him to leave or stay wherever he was (18.10). Even Paul's fateful trip to Jerusalem was due to the Spirit's constraint, only to take him eventually to Rome itself $(20.22-23 ; 23.11)$. These many examples are cited by Luke to show his readers that God directed the church's mission; using whatever means he desired to lead his servants according to His divine purpose.

An extraordinary display of the Lord's providence is seen in the way that He empowers His servant's ministry. Luke points out that when Peter speaks to the rulers and elders of the people that he was 'filled with the Spirit' (4.8). He who had not the courage to admit his connection with the Lord a few weeks prior now boldly answers them. This boldness was also given to the other believers in answer to their prayers in the face of persecution (4.2931). This empowerment is also seen in the many healings and wonders done among the people. Peter is empowered throughout Judea, Galilee and Samaria (9.32-42). Stephen had this power in Jerusalem and it eventually led to his death (6.8). Paul too had such supernatural empowerment to cast out demons, heal the sick, and even curse the wicked $(13.9-11 ; 14.3 ; 19.11-12 ; 20.10)$. Such power was a clear sign of God's presence with the believers, and especially His official representatives, the Apostles. Luke is clear in showing that this was God's power, for "God was doing extraordinary miracles by the hands of Paul" (19.11 - italics added). This empowerment acted not only as a sign of God's favour, but also as a demonstration that the kingdom of God had come in power, and was overcoming the forces of evil.

A fourth way in which Luke demonstrates God's providence is through the mouths of those proclaiming the Good News. Luke not only says it himself, he also points to how the Disciples spoke of God's sovereignty in the kerygma. First of all, Peter points out at the very beginning that what the people where witnessing at Pentecost was not the work of too much wine. It was the fulfillment of what God had spoken through the Prophet Joel (2.16$21)$ ! And then he proceeds to describe the recent events of Jesus life, death, and resurrection as the work of God Himself:

Jesus of Nazareth, a man attested to you by God with mighty works and wonders and signs that God did through him in your midst...this Jesus, delivered up according to the definite plan and foreknowledge of God, you crucified... God raised him up...Let all the house of Israel therefore know for certain that God has made him both Lord and Christ (2.22-36).

In every place that Peter proclaims these things he makes it clear that this was the work of a sovereign God who purposed and planned these things for their good! ${ }^{33}$ Stephen's speech in

See Acts 3.13-26;4.10-12;5.29-32;10.34-43. The predestination of Christ's suffering is also reflected in the prayer of the believers in 4:27-28. This shows that even the common believers understood and believed God's providence over the things that had, and were, occurring. 
Acts 7 reveals a belief in the providence of God. As he tells it, God's hand ruled over and accomplished God's purpose in the lives of Abraham, Joseph, Moses, Joshua, David and Solomon. And even though this speech led to the death of Stephen, God was with him in death. This too appears providential in that Luke portrays this as the spark of persecution that led the disciples to witness in the surrounding areas (chapter 7-8.8). Not only does Peter and others declare God's providence in the gospel to those in and around Jerusalem, Paul proclaims the same to the Jews and Gentiles of the Diaspora. His model sermon given to us in 13.17-41 is saturated with God as the primary actor in accomplishing their history and their salvation. Even the messages given to pagans ring with the same providential flavour. It is God (Yahweh) who made the world and who determines people's lifelines and boundaries. He is the one who provides for the world. And now God has appointed their resurrected Judge, Christ Jesus (14.14-18;17.22-31). And in Paul's last remarks to the Jews in Rome the note of divine providence is used to explain why many Jews continue to reject the Lord's good news about the kingdom of God. They are the people of Isaiah 6.9-10 (28.25-28). Therefore, we read from beginning to end the demonstration of divine providence at work through the proclamation of the early believers.

\section{Conclusion}

I have argued here that the doctrine of divine providence is found in the church's theology and writings from its very outset. One of the reasons why this study is important for the church today is that we can see the different points of view that go back to the $1^{\text {st }}$ century. The issues and debates revolving around God's providence are not new to us. Even the Jewish teachers and Greek philosophers had differing views of it. This did not begin with Luther and Calvin, or with St. Augustine and Pelagius. It also shows that Luke was working within a conceptual world that made sense to his readers. I have argued and demonstrated that Luke was able to adapt current notions of divine providence to the work of God, especially the Holy Spirit, in the formation and mission of the church. Luke demonstrates both cultural knowledge and 'Christian' creativity in interpreting the events of the early church to provide a theological framework for understanding God's work in their midst.

When we examine the Old Testament, the intertestimental literature, and the New Testament we find an understanding of God being immanent and transcendent, both great and close. God is the Creator of all things. God is Sovereign and always in control. Even if believers disagree over how providence works, it may be encouraging to remember this historical understanding - that God is the one and only true God, and has good purposes and plans. A solid knowledge of how God has proven faithful and providential in the past helps us who live in a world full of injustice, war, hunger, and other evils. God is still in control and able to provide for a disordered world in need of renewal. All that God has promised with the coming of Christ and his kingdom will eventually be realized - on earth as in heaven. Just as the Lord's providence gave birth to the church, and has empowered and directed her throughout history, God may be trusted to do the same today. Divine sovereignty informed the church's proclamation of the kingdom and God's grace back then, and it may serve us well today.

In all this we can see that Luke has provided a theologically sophisticated and contextually relevant picture of divine providence, here demonstrated as God at work, through the Holy Spirit, in the church and in the surrounding world. In Luke's account of both Jesus Christ (in his Gospel) and the early church (in Acts), it is clear that the providence of God is at work, and is acknowledged among the people. 


\section{BIBLIOGRAPHY}

Elwell, Walter A ed. 1996. "Providence of God". Evangelical Dictionary of Biblical Theology, Walter A Elwell, Grand Rapids: Baker Books.

Jervell, Jacob 1996. The Theology of the Acts of the Apostles. Cambridge: University Press. Powell, Mark Allan 1991. What are They Saying About Acts? New York: Paulist Press.

Talbert, Charles H ed. 1984. New Perspectives from the Society of Biblical Literature Seminar New York: Crossroad.

Cadbury, HJ 1927. The Making of Luke-Acts. New York: Macmillan.

Cosgrove, Charles H 1984. "The Divine Dei in Luke-Acts", Novum Testamentum XXVI:2.

Obitts, SR 1984. 'Epicureanism', Evangelical Dictionary of Theology, Grand Rapids:

Baker Books. start here

Farley, Benjamin 1988. The Providence of God; The Greek and Roman Philosophical Heritage. Grand Rapids: Baker Books.

Josephus 1904. Antiquities of the Jews, and Wars of the Jews. Trans. William Whiston, Lynn, Massachusetts: Hendrickson Publishers.

Morphew, Derek 2011. The Mission of the Kingdom. Cape Town: Vineyard International Publishing.

Seneca 1900. De Providentia, 4. Trans. William Bell Langsdorf, New York: GP Putnam's Sons.

Scott, J Julius Jr. 1995. Jewish Backgrounds of the New Testament. Grand Rapids: Baker Books.

Squires, John T 2004. The Plan of God in Luke-Acts. Cambridge University Press.

Thompson, Alan J 2011. The Acts of the Risen Lord Jesus: Luke's Account of God's

Unfolding Plan. Downers Grove: IVP.

Readings from the First Century World 1998. Edited by Walter Elwell and Robert W Yarbrough. Grand Rapids: Baker Books.

Hellenistic Commentary to the New Testament 1995. Edited by M Eugene Boring, Klaus Berger, and Carsten Cople. Nashville: Abingdon Press. 